\title{
REGIONAL RISK ASSESSMENT OF HIGHLY PATHOGENIC AVIAN INFLUENZA IN THE BORDER OF INDONESIA AND MALAYSIA: A SOCIO ECONOMIC PERSPECTIVE
}

\author{
Nyak Ilham and Muhammad Iqbal \\ Indonesian Center for Agriculture Socio Economic and Policy Studies (ICASEPS) \\ Jalan Ahmad Yani 70, Bogor 16161, Indonesia \\ E-mail:ny4kilham@yahoo.com and iqbalrafani@yahoo.com
}

\begin{abstract}
Abstrak : Hasil kajian menunjukkan bahwa tingkat penelusuran penyakit flu burung baik secara positif maupun negatif tergolong masih rendah karena luasnya cakupan areal dan kurangnya laporan kasus dari peternak unggas. Koordinasi diantara institusi lintas batas relatif masih lemah sehingga perdagangan ilegal masih terjadi baik melalui pintu pemeriksaan maupun pintu masuk lainnya di sepanjang wilayah lintas batas. Pergerakan unggas hidup dan produk unggas masih berisiko karena para pedagang cenderung secara aktif mengunjungi dan mengumpulkan ternak unggas di kandang. Terdapat beberapa kendala terkait dengan sosial budaya setempat seperti acara pesta yang cukup tinggi mengkonsumsi daging unggas dan kegiatan sabung ayam di beberapa lokasi tertentu. Sistem penulusuran penyakit flu burung secara positif bersamaan dengan kampenye zoonosis seyogianya diterapkan untuk mendapatkan data dan informasi seraya menggugah para peternak unggas agar memberikan laporan tentang kasus flu burung di wilayah mereka.
\end{abstract}

Kata Kunci: flu burung, pengkajian risiko, sosial ekonomi, perbatasan IndonesiaMalaysia

\begin{abstract}
The result of the study shows that the extent of both active and passive surveillance was still low due to large coverage area and lack of report cases of Highly Pathogenic Avian Influenza (HPAI) from poultry farmers. The level of coordination among cross-border institutions was still relatively worst so that the illegal trade was still occurred in the checkpoints and other entry points along the cross-border line. The movement of poultry and poultry products was still risky since the traders tend to be actively visiting and catching the poultry in the sheds. There were some handicaps in line with local socio culture such as multi events festivity with high consume of chickens and cock fighting activity in some spotted areas. It is suggested that active surveillance system together with zoonotic campaign should be implemented in order to obtain the immediate data and information as well as to attract poultry farmers to provide reporting on the case of HPAI in the respected areas.
\end{abstract}

Keywords: HPAI, risk assessment, socio economic, Indonesia-Malaysia border

\section{INTRODUCTION}

\section{Background}

Regionally, the trans-boundary aspect of the spread of Highly Pathogenic Avian Influenza (HPAI) remains one of the major challenges in the fight against HPAI. Although it is difficult to identify the origin of HPAI outbreaks, many previous studies in the region have revealed the significant contribution of cross-border trade to the national supply of poultry and poultry products (Rushton, et al, 2009).

The cross-border study should be necessarily conducted since it may elucidate some aspects such as trade regulations, epidemiology and socioeconomic patterns, government organizations, and technology implementations affecting the HPAI occurrence 
and control. These circumstances may affect on movements of poultry and poultry products, whether legal or illegal.

By understanding the cross-border transmission of HPAI with complex interaction linkages to socioeconomic institution and some trade chain studies are merely inadequate to be referred as a comprehensive guideline for controlling the HPAI. Nevertheless, those can be employed as an additional (supplement) study required to explore the cross-border area with high risk of HPAI at initial or the subsequent transmission or both, and other factors specifically related to the type of HPAI itself.

\section{Objectives}

The general objective of this study is to characterize the cross-border area which has potential risk for HPAI. Specifically, this study aims at: (1) analyzing the history of the presence of the disease and current presence or absence of HPAI outbreaks in the area; (2) reviewing the current knowledge of crossborder areas of potential high risk of HPAI in line with trade, the prevailing legal framework and animal health cooperation across borders; (3) identifying and characterizing the poultry production system as well as the surveillance and control measures in place for HPAI; (4) identifying the presence of high-risk species, high-risk spots or high-risk husbandry practices; and (5) identifying and analyzing the value chain of cross-border poultry and poultry products: flow, type of poultry and poultry products traded, market, supporting factors of poultry and poultry product movement, price, culture, and consumer preferences.

\section{METHODOLOGY}

\section{Conceptual Framework}

The characteristics of cross-border areas are essential to be studied mainly in terms of epidemiological and socioeconomic aspects as policy recommendations on HPAI control, especially in the study sites. The epidemiological aspect includes four indicators while the socioeconomic aspect covers eight indicators (FAO-ECTAD-RAP, 2010).

The conceptual framework of this study can be seen in Figure 1. The HPAI control can be carried out through investigation (risk assessment) employing epidemiological and socioeconomic indicators towards poultry and poultry products affect on HPAI transmission in cross-border area.

\section{Study Site and Schedule}

The study was conducted in two provinces in Kalimantan (Indonesia) bordered with Malaysia. First, West Kalimantan

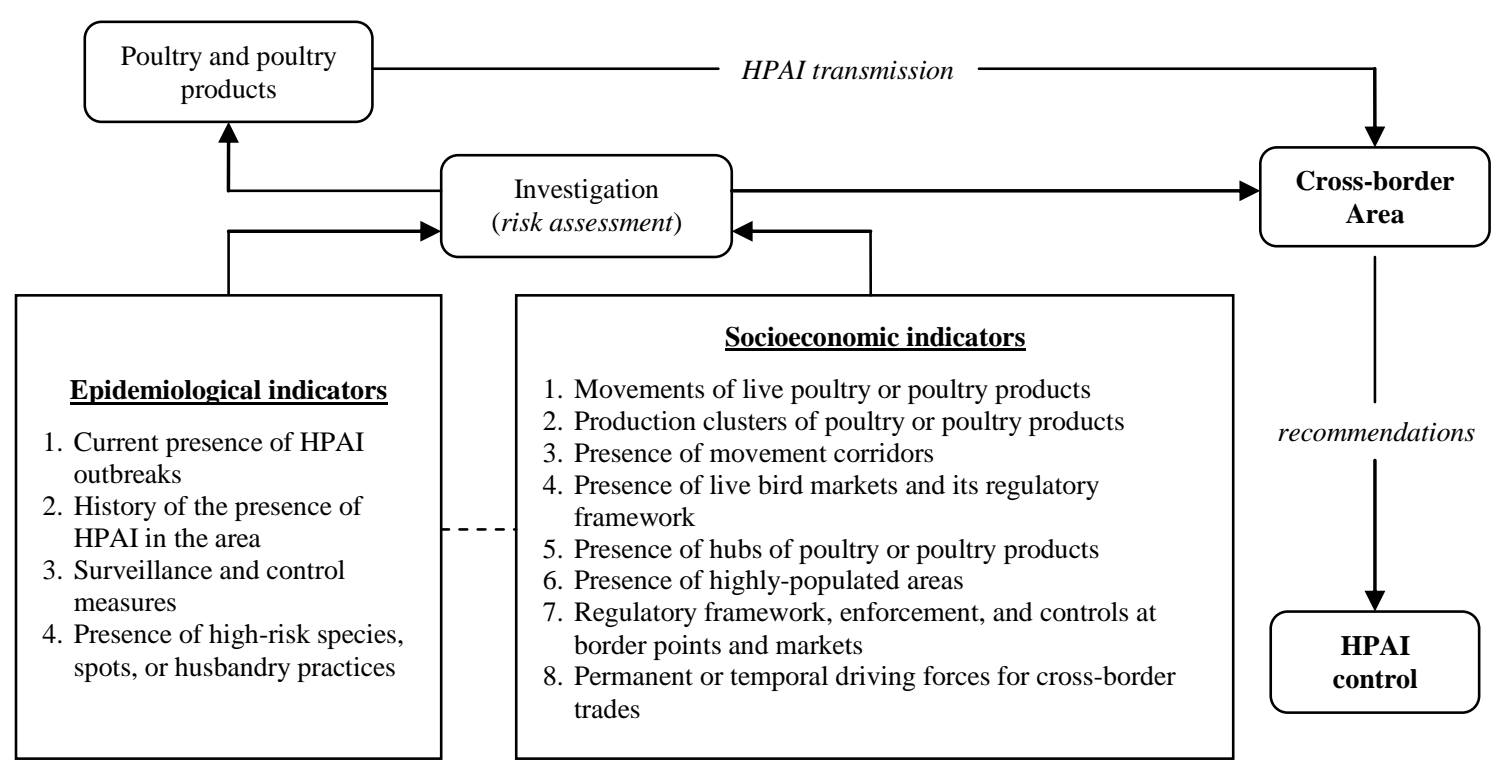

Figure 1. Conceptual framework of the study 
Province bordered with Sarawak State in which two districts was selected, namely Sanggau district (border checkpoint in Entikong) and Bengkayang District (border checkpoint in Jagoi Babang). Second, East Kalimantan Province (bordered with Sabah State) represents Nunukan District with border checkpoint in Sebatik.

Data were collected in two-phase (May to June 2010 and July to August 2010). Phase I includes pre-survey with the purpose of: (1) collecting secondary data; (2) determining location for main survey; (3) testing questionnaire; and (4) preparing main survey participated by relevant institution/ stakeholder(s). Phase II comprises main survey covering data collection from respondents through interview method using questionnaire, Focus Group Discussion (FGD), and direct observation along the market chain of poultry and poultry products in the study sites.

\section{Data Sources and Analysis}

The study covers primary and secondary data. The primary data were collected from 51 respondents in each province, namely at provincial, district, sub-district/village, and cross-border levels. It comprises traders, poultry farmers and its associations, and formal/informal leaders. Meanwhile, the secondary data derives from reports and other related documents at respective institutions such as livestock/veterinary, trade, statistics, custom/immigration, quarantine, police, army, and navy.

Data were analyzed descriptively using semi quantitative approach (cross tabulation) towards 12 indicators of epidemiological and socioeconomic aspects (FAO-ECTAD-RAP, 2010). All indicators were assessed allocating a risk score: 0 (no risk), 1 (low risk), 2 (medium risk), and 3 (high risk).

\section{RESULTS AND DISCUSSION}

The summary of assessment results of the risk indicators of this study is presented in Table 1 . It covers four epidemiological indicators and eight socioeconomic indicators assessed by a risk score. The epidemiological indicators cover: (1) current presence of HPAI in the area;

Table 1. Summary of assessment results of the risk indicators of cross-border study sites

\begin{tabular}{|c|c|c|c|c|c|c|c|c|c|}
\hline \multirow{3}{*}{ No. } & \multirow{3}{*}{ Risk Indicator } & \multicolumn{8}{|c|}{ Risk Score $^{*}$} \\
\hline & & \multicolumn{4}{|c|}{ West Kalimantan } & \multicolumn{4}{|c|}{ East Kalimantan } \\
\hline & & 0 & 1 & 2 & 3 & 0 & 1 & 2 & 3 \\
\hline \multirow[t]{5}{*}{ A. } & Epidemiological indicators: & & & & & & & & \\
\hline & 1. Current presence of HPAI in the area & & 1 & & & & 1 & & \\
\hline & 2. History of the presence of HPAI in the area & & 1 & & & & 1 & & \\
\hline & 3. Surveillance and control measures & & & & 3 & & & & 3 \\
\hline & $\begin{array}{l}\text { 4. Presence of high-risk species spots, high risk } \\
\text { spots, or husbandry practices }\end{array}$ & & 1 & & & & & 2 & \\
\hline \multirow[t]{11}{*}{ B. } & Socioeconomic indicators: & & & & & & & & \\
\hline & 1. Movements of live poultry or poultry products & & & 2 & & & & & 3 \\
\hline & $\begin{array}{l}\text { 2. Production clusters of poultry or poultry } \\
\text { products }\end{array}$ & & 1 & & & & & 2 & \\
\hline & 3. Presence of movement corridors & & 1 & & & & & 2 & \\
\hline & $\begin{array}{l}\text { 4. Presence of live bird markets and its regulatory } \\
\text { framework }\end{array}$ & & & 2 & & & & 2 & \\
\hline & 5. Presence of hubs of poultry or poultry products & & 1 & & & & & & 3 \\
\hline & 6. Presence of highly-populated areas & & 1 & & & & 1 & & \\
\hline & $\begin{array}{l}\text { 7. Regulatory framework, enforcement, and } \\
\text { control at border points and markets }\end{array}$ & & 1 & & & & 1 & & \\
\hline & $\begin{array}{l}\text { 8. Permanent or temporal driving forces for cross- } \\
\text { border trades }\end{array}$ & & & 2 & & & & 2 & \\
\hline & Total Risk Score & & 8 & 6 & 3 & & 4 & 8 & 9 \\
\hline & Overall Risk Score $^{2\rfloor}$ & & & & & & & & \\
\hline
\end{tabular}

Note: ${ }^{*} 0$ (no risk); 1 (low risk); 2 (medium risk); 3 (high risk)

${ }^{* *}$ 0-12 (low risk); 2-24 (medium risk); 24-36 (high risk) 
(2) history of the presence of HPAI in the area; (3) surveillance and control measures; and presence of high-risk species spots, high risk spots, or husbandry practices. On the other hand, the socioeconomic indicators comprise: (1) movements of live poultry or poultry products; (2) production clusters of poultry or poultry products; (3) presence of movement corridors; (4) presence of live bird markets and its regulatory framework; (5) presence of hubs of poultry or poultry products; (6) presence of highly-populated areas; (7) regulatory framework, enforcement, and control at border points and markets; and (8) permanent or temporal driving forces for cross-border trades

\section{Current Status of HPAI in the Area}

The current status of HPAI in two provinces was reported by the respective local institution (LDCC-WK, 2010 and LDCC-EK, 2010). First, the HPAI case in West Kalimantan Province was currently found in native chickens (328 cases with 5,100 poultry dead) and ducks (1 case with 150 poultry dead). Presumably, the source of re-occurrence of HPAI in West Kalimantan Province was native chicken (particularly cock fighting) from Madura island that beyond the livestock and quarantine controls. One of the modus operandi of delivering the cock fighting to this province was through shipping boats stopped by community before entering the port. This is because the high demand for cock fighting in which the cock fighting from outside has stronger in terms of fighting power as compared to local cock fighting. Second, in East Kalimantan Province, the HPAI incidence was only discovered at native chickens (45 cases with 201 poultry dead). Nevertheless, since the cross-border study site has no current case of HPAI, the status of these areas can be categorized as low risks ( score $=1$ ).

\section{History of the Presence of HPAI in the Area}

HPAI in West Kalimantan Province, particularly in Pontianak City and Kubu Raya District, was initially found in 2004 (LDCCWK, 2010). At this time, according to Hadi (2010), the disease caused 20,800 broiler chickens dead or 72 percent of the total broiler chickens $(28,800$ birds) in these district and city. Meanwhile, there were no HPAI cases in other districts and cities. There were no official reports on the number of HPAI cases and poultry deaths during 2005-2009.

The general chronology of HPAI case in East Kalimantan Province are as follows (LDCC-EK, 2010): (1) in 2005 (sporadic); (2) in 2006 (decrease); (3) in 2007 (outbreak); (4) in 2008 (free); (5) in 2009 (free); and (6) in 2010 (minor). The transmission of HPAI was mainly due to the trade movements i.e., from South Kalimantan Province that beyond the control (checkpoint) of local authorities such as Livestock and Quarantine Offices. During 2005-2009, there were no official reports on the number of HPAI cases and poultry deaths in this province.

It was noted that the cross-border study sites in both provinces had never experience with HPAI. Consequently, the risk of these areas can be assessed as low risks (

\section{Surveillance and Control Measures}

Surveillance is one of important factors in controlling the HPAI. The surveillance activity is mainly conducted by the Participatory Disease Surveillance and Response (PDSR) team under Local Disease Control Center (LDCC). The number of PDSR officers in West and East Kalimantan Provinces was 33 persons and 22 persons, respectively. On average, the number of PDSR officer was two persons per district/city in West Kalimantan Province and one person per district/city in East Kalimantan Province (LDCC-WK, 2010 and LDCC-EK, 2010). In fact, these numbers were not sufficient as compared to the area size and limited accessibility in both provinces. This is in line with the study result of Ilham and Iqbal (2011), in which HPAI is a new disease while the number of animal health officers including PDSR responsible in HPAI control measure was still limited as compared to their working areas.

Apart from surveillance, other activities was implemented by local authorities such as focal culling ${ }^{1]}$, disinfection, vaccination, tight control of HPAI virus media derived from outside. In West Kalimantan Province, during 2004-2006, about 792 liters of disinfectant

\footnotetext{
1] Identifying, destroying, and removing only those birds that are sick and infected or those birds that have had contact with the sick or infected birds (USAID, 2007).
} 
were used in seven districts/cities. In addition, $5,889,140$ doses of HPAI vaccine were particularly applied in poultry sector-4.

During 2005-2009, the activities of surveillance and virology test focused on epidemiological such as sensitivity and specificity of PCR (Polymerase Chain Reaction) rapid test based on one percent of assumed prevalence and 95 percent of confidential level. It covered nine district/city samples (22 sub-district samples and 40 village samples) and 162 backyard poultry farmers. About 342 pool swabs and 1,011 serum samples were tested in serology laboratory. There were two main results of these activities. First, there were no genetic materials of HPAI virus based on swab sample test. Second, there was high antibody titer $(1.79 \%$ to $48.94 \%)$. Base on the comprehensive activities supported by the Expert Member Commission and facilitated by the National Committee for Avian Influenza Control and Pandemic Influenza Preparedness (Komnas Flu Burung); therefore, West Kalimantan Province was declared as free zone of HPAI in January 2010 (LDCC-WK, 2010).

The significant activities of HPAI control measures in East Kalimantan Province were focal culling and vaccination. About 106,825 native chickens were aggregately vaccinated during 2006-2007 and 4,344 native chickens were depopulated through focal culling program in 2007 (LDCC-EK, 2010). Most of focal culling was implemented voluntarily (without compensation).

Based on field survey, some phenomena were found in the cross-border study sites. First, the level of knowledge of local farmers about HPAI such as clinical signs and zoonotic diseases were relatively low, particularly smallholders or backyard poultry farmers. Second, reporting of suspect cases by farmers was predominantly derived from broiler and layer chicken farmers. Native chicken farmers tend to report the case of poultry death in highly populated areas. Third, there was time gap between notification, confirmation, and action of HPAI control measure due to limited reporting from farmers as well as lack of number animal health officers and budget availability. Fourth, level of cooperation between poultry farmers and private veterinary officers (private technical services) was higher comparing to the level of cooperation between poultry farmers and official veterinary services. This was because private veterinary officers were more pro-active to approach poultry farmers (particularly broiler and layer chickens) while official veterinary staff had limited human and budget resources in line with large coverage area of services. Fifth, the level of provision of official veterinary services was relatively limited. It is substituted by private technical services and input traders which usually incorporated in business transaction with poultry farmers. Sixth, active surveillance activities implemented or ongoing in the area (surveys including sampling and testing or just participatory surveillance) were relatively more focused on central producing areas of poultry. Seventh, sampling and testing of live poultry for HPAI were mainly implemented based on clinical sign and mass poultry deaths. Eighth, bio-security plans in affected and non-affected areas have not fully implemented yet. Conclusively, the risk indicators of the surveillance activities in the area and the effectiveness of control measure risks of the cross-border study sites can be categorized as high risk $($ score $=3$ ).

\section{Presence of High-risk Species, Spots, or Husbandry Practices}

The observable fact shows that the presence of duck farms in Sanggau District (West Kalimantan) was quite low. The majority of ducks were free ranging in the backyards, rice fields, and ponds. The plan intensity of rice fields in this district was generally low (once planting rice a year). It was found that ducks in the rice fields and ponds nearby forest areas interact with native chickens and wild birds such as wild ducks and sparrows.

Ducks were free-roamed at rice fields in the study site of East Kalimantan Province. The plant intensity of rice field in this area was once or twice a year (depend on water/irrigation availability). There were no found scavenging birds in the land areas instead of eagles in coastal areas. In addition, there were no exotic birds in this area.

It was observed that there were some scares scavenging birds at the study sites in West Kalimantan Province, namely eagles and crows. Another bird (swallow nest) was raised 
by local community. Among other species with low interaction with raised poultry were hornbills, starlings, parrots, flamingos, pigeon, and turtledove. The presence of cock fighting derives from East Java (Java's cock fighting) and Malaysia (Philippines's cock fighting). Meanwhile, the presence of migratory birds is currently low since the development of residential areas and forest exploitation are quite intensive in the study sites.

The presence of cock fighting at the study site in East Kalimantan Province was related to the social culture of local community. Some cock fighting activities still exist in spotted areas even the government has already implemented the rule of prohibited cock fighting in the study site. It was found mangrove plants along the coastal line but the observable fact showed that wild birds did not exist in this area.

Most of broiler chicken farmers in both study sites (West and East Kalimantan Provinces) were concern with the movement of catching crews than the movement of catching equipment from one farm to another. Moreover, the poultry production cycle was more important than bio-security measures. Overall, the risk indicators of the high-risk species, high-risk spots or high-risk husbandry practices of the cross-border study sites in West and East Kalimantan Provinces were low risk $($ score $=1)$ and medium risk $($ score $=2)$, respectively.

\section{Movements of Live Poultry or Poultry Products}

Some data were obtained from the field survey (interview with key informants, focus group discussions, and direct observations). First, about 250-350 kilograms of frozen broiler carcasses were daily supplied from Malaysia to Indonesia through Entikong checkpoints using pick-up vehicles (vans) to West Kalimantan border areas (for local consumers) and accumulatively delivered to Pontianak (capital city of West Kalimantan Province) using trucks/lorries (for supermarkets). Second, about 25-30 live birds (native chickens and ducks) were daily traded between Indonesia and Malaysia (vice versa) and can be increased to 50-100 live birds during the social cultural and religious ceremonies.
Transportation cost of poultry and poultry products from Malaysia to Indonesian border areas was amounted about IDR 200 per kilogram while the transportation cost of poultry and products from central poultry producing areas of West Kalimantan Province (Pontianak and Singkawang Cities) was about IDR 350-350 per kilogram. Hence, the supply quantity of poultry and poultry products from Malaysia was higher than that from domestic due to different cost of transportation. About 70 percent of eggs and 20 percent of live chickens were supplied from Malaysia to Indonesian border areas.

Currently, the price of frozen broiler carcass from Malaysia in the border areas of Indonesia was about IDR 18,000-20,000 per kilogram while live broiler chicken was about IDR 21,000-23,000 per kilogram (1.5-1.8 $\mathrm{kg} / \mathrm{bird})$. Meanwhile, the price of eggs from Malaysia (IDR 950-1,000/egg) was cheaper than the price of eggs from domestic (IDR $1,100-1,200 / \mathrm{kg}$ ).

It was noted that the mortality rate of broiler chickens during transportation (most of them was hit stress) was about 1-2 percent per trip. The mortality risk responsibility was based on agreement under poultry sellers and buyers.

In the case of border areas in East Kalimantan Province, poultry and poultry products can be "inward and outward" traded either from domestic or abroad (Malaysia). The means of transportations used were speedboat, ferry, and cargo/passenger ships. About 80 percent of broiler and egg consumed by community of Nunukan district were supplied from Malaysia.

The actors of poultry trade were traders or the owner of speedboats who can order poultry products to distributor in Tawau through telephone communication directly. Even though the government has launched the Law Number 18/2009 issued on livestock and animal health, the illegal trading of poultry products from Malaysia still exist particularly in the cross-border areas.

Due to different phenomena of the movements of live poultry between the crossborder areas of West and East Kalimantan Provinces, the risk indicators for this aspect were also vary. The risk indicators of the movements of live poultry or poultry products within the area, across the border/s and to other 
destinations production clusters of poultry or poultry products of the cross-border study sites in West Kalimantan Province can be categorized as medium risk ( score $=2$ ) while in East Kalimantan Province was high risk (score $=3$ ).

\section{Production Clusters of Poultry or Poultry Products}

The poultry in West and East Kalimantan Provinces was respectively under independent and partnership management systems. Broiler and layer chicken layer farms (poultry sector-3) were more concentrated in the surrounding urban areas that have high accessibility to the provisions of capital and input, the presence of transportation, and the existing consumers. However, the broiler and layer chicken sheds were located outside community residences because the availability of unoccupied land in both provinces was still relatively outsized. Backyard poultry (sector-4) including native chickens, ducks, and quails was primarily raised as an additional activity by rural community surrounding the residence areas. Meanwhile, the raising and activity of cock fighting can be found in spotted areas. This poultry particularly derived from outside such as Java and Madura islands as well as Philippines that potentially transmitted the HPAI to these provinces.

West and East Kalimantan Provinces have owned broiler-breeding farms to fulfill the domestic needs and some were supplied to other provinces such as Central Kalimantan. However, the DOCs (Day Old Chickens) of layer chicken and DODs (Day Old Ducks) still derived from outside (West and East Java Provinces). Poultry was slaughtered in the traditional markets or residential traders. Both provinces have no facilitates of poultry processing unit. Chicken manures were processed organic fertilizer for oil palm plantation in West Kalimantan Province and horticulture as well as fish/shrimp ponds. Both provinces have no owned feather warehouses.

Due to long distance of cross-border areas to central domestic producing areas of broiler and layer chickens, most of poultry and poultry products were supplied from Malaysia. Overall, indicators of the productions clusters of poultry and poultry products risks of the cross-border study sites was low risk in West Kalimantan Province (score $=1$ ) and medium risk in East Kalimantan Province (score $=2$ ).

\section{Presence of Movement Corridors}

There are five districts, 15 sub-districts, and 140 villages in West Kalimantan Province located in the border areas along 897 kilometers with Malaysia. The areas include one established checkpoint (Entikong), four planned checkpoints (Aruk, Jagoi Babang, Jasa Senaning, and Nanga Badau), and about 64 footpaths. The movement of poultry and poultry products in the cross-border study site was transported by car, motorbike, and men. Despite the study site was free of HPAI, the disease can be transmitted through these means of transportation.

The cross-border study site in East Kalimantan Province is located in Sebatik Island. This island consists of two areas (Indonesian in southern part and Malaysia in northern part). Both areas are bordered by river and land. Means of transportation of poultry and poultry product movements were four wheel drive and motorbike (in Sebatik) and boat (to Tawau, Malaysia).

Even though the cross-border study site was relatively free of HPAI, the disease can be generally transmitted to this area through the two movement corridors of the point/s of origin of poultry and poultry from outsides. First, anecdotal evidence showed that one district in Sabah state (Malaysia) had ever positively infected by HPAI. Second, the HPAI potentially derives through supplying the eggs from South Sulawesi categorized as one of infected provinces of HPAI in Indonesia.

Aggregately, indicators of movement corridor risks in the cross-border study sites can be respectively categorized as low risk (score $=$ 1) in West Kalimantan Province and medium risk (score $=2$ ) in East Kalimantan Province).

\section{Presence of Live Bird Markets and Its Regulatory Framework}

Live Bird Markets (LBMs) still exist at the levels of national, regional, and local in Indonesia. Even though government has already established a special place for LBMs in traditional markets, some traders still put up for sale the poultry at some spot areas within the 
market. The LBMs were more favorable among lower income class of community due to cheaper price, simply bargained, close to residential areas, and slaughtered in place. The latter was a basic reason for community since they were able to observe the method of slaughter in line with religious (Islam) practice (halal/permitted). This condition has a highrisk in terms of HPAI transmission but up to present, there were no report cases of this disease at LBMs in the study areas.

In fact, there were some disadvantages of traditional markets including the LBMs in Indonesia particularly at the study sites. Among other things, they were: (1) low awareness of community towards cleanness and discipline attitude (law and order); (2) ineffective management of market institution; (3) inappropriate management of Standard Operating Procedures (SOPs); (4) unaccountable financial management; (5) low consciousness of the maintenance of physical facilities; and (6) unorganized selling the products.

In the study site of West Kalimantan Province, all small-scale broiler chicken farms were marketed to traditional markets, while large-scale broiler chicken farms were supplied to traditional markets $(70-80 \%)$ and to supermarket (20-30\%). Frozen broiler carcasses from Malaysia were delivered to supermarket $(70 \%)$ and traditional markets $(30 \%)$. In the study site of East Kalimantan Province, live poultry were derived from domestic and the rest from Malaysia. However, either fresh or frozen carcasses were predominantly supplied from Malaysia.

The observable fact showed that the legal and illegal poultry and poultry products could be found in traditional markets both in the study sites of West and East Kalimantan Provinces. Hence, the risk indicators of the presence of local and/or regional LBMs and/or poultry product markets and regulatory framework at markets in the cross-border study sites of West and Kalimantan Provinces can be categorized as medium risks ( $($ core $=2$ ).

\section{Presence of Hubs of Poultry and Poultry Products}

West Kalimantan Province has two checkpoints in Entikong (Sanggau District) and Jagoi
Babang (Bengkayang District). These checkpoints are quite far from central domestic poultry producing areas and relatively close to central poultry producing areas of Malaysia. It was informed that Malaysia has integrated poultry farms (input, slaughtering, and processing facilities). Therefore, the majority of poultry products particularly frozen carcasses and eggs were supplied (legal and illegal) from Malaysia (Tebedu, Sarawak State) to Indonesian border and it was occasionally delivered to Pontianak. The observable fact showed that the frozen carcasses from Malaysia had labeled with halal (permitted), veterinary inspected, expire date, and the Hazard Analysis Critical Control Points (HACCPs).

The cross-border checkpoint has a parking area but it was more functioned as a media transfer of goods including poultry products from Malaysia. Subsequently, the poultry products were transported using vans (to Indonesian border) and trucks/lorries (to Pontianak).

Likewise, East Kalimantan Province has two checkpoints in Nunukan and Sebatik Islands. However, some poultry and poultry products from Malaysia (Tawau, Sabah State) were directly delivered to public (informal) ports such as Yamaker, Laloselo, and Aji Kuning using speedboats. It was estimated that about 80 percent of poultry and poultry products from Malaysia were supplied to Indonesian border areas.

The risk indicators the presence of hubs of poultry and poultry products of the crossborder study sites can be determined as low risk (score $=1$ ) in West Kalimantan Province and high risk (score $=3$ ) in East Kalimantan Province.

\section{Presence of Highly Populated Human Areas}

Indonesia consists of 33 provinces with total land area of about 1,922,570 square kilometers and population of $237,000,000$ people. Meanwhile, West and East Kalimantan Provinces have land areas of about 146.807 square kilometers and 198,441 square kilometers, respectively. Total population of these provinces is 4,249,117 people (West Kalimantan) and 3,094,700 people (East Kalimantan). West Kalimantan consists of 12 
districts and 2 cities while East Kalimantan Province comprises 10 districts and 4 cities.

The population density of West and East Kalimantan Provinces is lower than national, Java, and off-Java population densities. Table 15 shows that population density of West and East Kalimantan Provinces (29 people/sq km and 16 people/sq $\mathrm{km}$, respectively) as compared to national (120 people/sq $\mathrm{km})$, Java $(1,026 \mathrm{people} / \mathrm{sq} \mathrm{km})$, and off-Java (54 people/sq km) population densities. Likewise, the population density of district study areas was lower than population densities of other districts within province.

Among other highly populated areas in the area were tourist resorts and pilgrimage sites. These areas were mainly visited by local community. Apart from that, the military camps can be found in strategic location related to the security and defense areas. It was noted that areas of slums or poor communities of displaced, migrants; and/or refugee camps or migrants were not found in the area of the studies.

Aggregately, the presence of highly populated human areas risk of the cross-border study sites was assessed. Because the crossborder study sites had never experience with HPAI, the risk of these areas can be assessed as low risks $($ score $=1)$.

\section{Regulatory Framework, Enforcement, and} Status of Controls at Border Points

Essentially, the regulatory framework and enforcement of HPAI control at border points are anchored in socioeconomic cross-border aspects and technical livestock practices. Indonesia has organizes border areas under Law Number 43/2008 issued on country area including border areas. First, local government has an authority to implement autonomous policy in border areas (chapter 11, article 1). Second, the Government of Indonesia (GoI) establishes border institution at national and local levels (chapter 14, article 1). The latter has been enforced under Presidential Regulation Number 12/2010 issued on the establishments of border institution such as the Agency for Border Area Management and Cooperation (West Kalimantan Province) and the Agency for Border and Remote Areas Management (East Kalimantan Province).
Indonesia and Malaysia has formulated Border Trade Agreement (26 May 1967) and Socioeconomic Malindo (Malaysia-Indonesia) Task Force (12 May 1984). One of essential points in both agreement and task force was free tax for trade commodities at maximum value of MYR 600 (about IDR 1,680,000) per month. Due to economic development progress in both countries, the free tax was planned increasing to the maximum value of about USD 1,500 (IDR 1,500,000) per month ${ }^{2]}$. Apart from that, based on agreement between immigration institutions of Indonesia and Malaysia, both citizens particularly in West and East Kalimantan Provinces are allowed to use crossborder document (alternative passport) such as for governmental duties, social/religious activates, and visiting family.

In terms of technical livestock aspect, the GoI has established Law Number 18/2009 issued on livestock and animal health. This law has been enforced by Minister of Agriculture Regulation Number 20/Permentan/OT.140 /4/2009 issued on import and distribution control carcasses, meat, and/or innards. The later regulates that carcasses and Mechanically De-boned Meat (MDM) should be free of HPAI and certified by respective animal health authorities.

The enforcement of the aforementioned regulations has been implemented by related institutions. In addition, some co-ordinations have been established among respective institutions at national, provincial, and crossborder levels. Nevertheless, the regulations were frequently implemented based on functional tasks of related authority. Hence, some illegal commodities including poultry and poultry products were traded between countries (Indonesia and Malaysia).

In order to fulfill the supplies of poultry and poultry products in West and East Kalimantan Provinces, the local authority (livestock and quarantine offices) launched the special policy issued on imported frozen meats for supermarket (West Kalimantan) and live poultry and poultry products for community (East Kalimantan). It is required that all

\footnotetext{
2] Average exchange rate of the currencies of Indonesian Rupiah (IDR) to Malaysian Ringgit (MYR) and United Stated Dollar (USD) at the time of field study was IDR 2,800 per MYR and IDR 10,000 per USD 1, respectively
} 
imported poultry and poultry products must be free from HPAI and under the criteria of $A S U H^{3]}$.

Poultry and poultry products were predominantly marketed in traditional market. Those can be found in special place (together cow meat and fish commodities) and in several parts (retail) of traditional market. The extent of biosecurity implementation was quite low. The trade of live birds and frozen carcasses as well as simple slaughter facilities mixed in same sites. Unsold live birds were kept in market kiosks. Poultry (chickens and ducks) and poultry products (eggs) were marketed separately within same market place.

The regulatory framework of control at the cross-border study sites was comprehensively established but the level of enforcement and implementation of the regulation was quite low. Therefore, risk indicators of regulatory framework, enforcement and status of controls at border points of cross-border study sites can be categorized as low ( score $=1$ ).

\section{Permanent or Temporal Driving Forces for Cross-border Trade}

Consumer demand for poultry and poultry products in the cross-border study site in West Kalimantan was determined by economic (price, income, and purchasing power) and social (culture and religious) aspects. Educated and rich communities relatively tend to consume poultry and poultry products daily while other communities temporally consume the poultry during social and religious ceremonies.

There was a significant level of social welfare between the communities of Indonesia and Malaysia border areas. First, agricultural system and productivity of Indonesian were relatively left behind as compared to Malaysia. Second, the daily wage rate of Indonesian employment was lower than that of Malaysian (IDR 30,000/person vs. MYR 15 or about IDR 42,000/person). Third, Malaysia was more developed than Indonesia in terms of infrastructure facility. Fourth, Malaysia implements economic development approach while Indonesia employs security approach.

Generally, the price and availability of poultry and poultry products in cross-border areas of West and East Kalimantan Provinces were high and deficit, respectively. Consequently, the needs of local community for poultry and poultry products should have fulfilled from outside either from domestic or from Malaysia. Figure 2 illustrates the different prices of poultry and poultry products among several areas in West Kalimantan Province. On the other hand, the example of prices of buying and selling poultry and poultry products in East Kalimantan Province can be seen in Table 2.

The exchange rate of IDR (Indonesian Rupiah) and MYR (Malaysian Ringgit) was recently stable (MYR 1 was equal to IDR 2,800). Nevertheless, during the economic crises in Indonesia (1998), many products from Indonesia marketed to Malaysia. Hence, the exchange rate potentially influences the risk of cross-border trade in the respected areas. Indicators of permanent or temporal driving forces for cross-border trade risks of crossborder study sites can be classified as medium risk $($ score $=2)$.

\footnotetext{
3] $A S U H$ (an Indonesian term) stands for Aman (safe), Sehat (healthy), Utuh (whole/intact), and Halal (permitted). Aman (safe), it does not contain

biological, chemical, or physical danger causing risk to human health; Sehat (healthy), it contains useful substances needed for human health and growth; Utuh (whole/intact), it is not mixed with other parts of the animal or parts of another animal; and Halal (permitted), it is slaughtered and handled based on Islamic Law (DGLS-MoA, 2006).
} 
Nyak Ilham and M.Iqbal: Regional Risk Assessment Of Highly Pathogenic Avian Influenza...

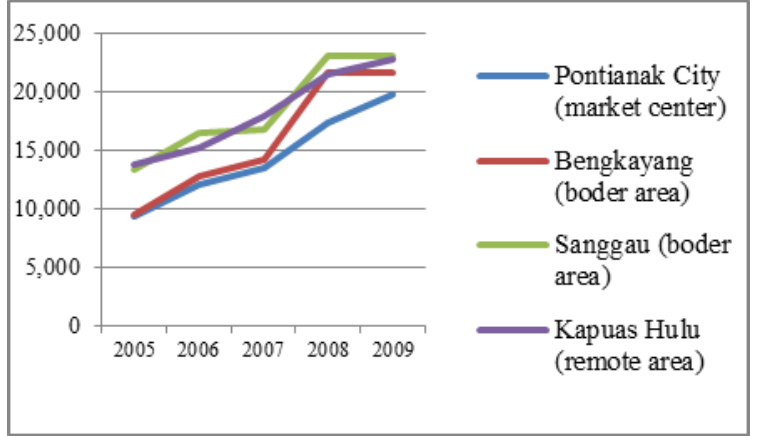

Yearly price of live broiler chicken, 2005-2009 $(\mathrm{IDR} / \mathrm{kg})$

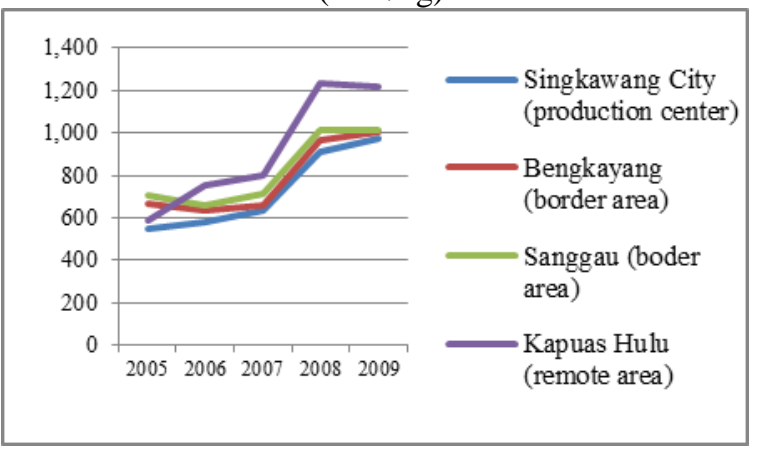

Yearly price of layer chicken egg, 2005-2009 (IDR/egg)

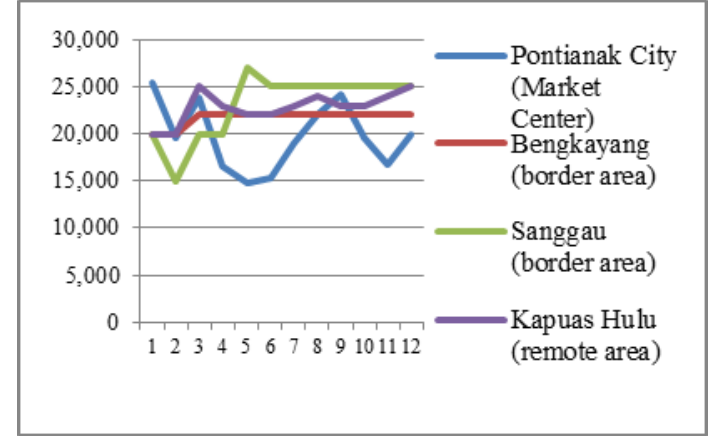

Monthly price of live broiler chicken, 2009 (IDR/kg)

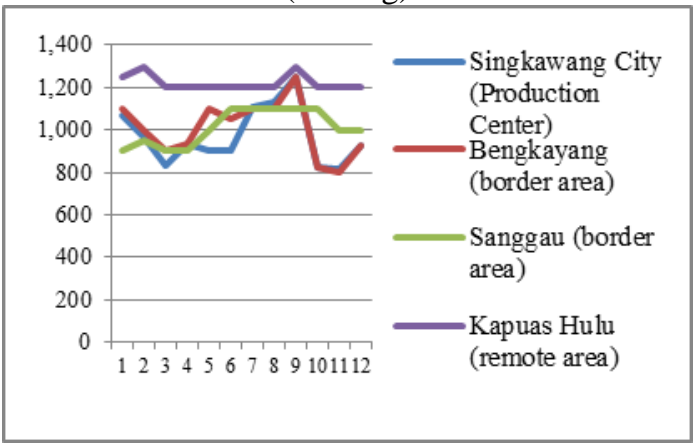

Monthly price of layer chicken egg, 2009

(IDR/egg)

Figure 2. Yearly and monthly prices of live broiler chicken and layer chicken egg in West Kalimantan Province (source: CBS-WK, 2010)

Table 2. Buying and selling prices of poultry products from Tawau (Malaysia) in Nunukan and Sebatik (Indonesia), August 2010

\begin{tabular}{cllrrrrr}
\hline \multirow{2}{*}{ No. } & \multicolumn{1}{c}{ Location } & \multicolumn{1}{c}{ Product } & \multirow{2}{*}{ Unit Price } & \multirow{2}{*}{ Buying } & Selling & $\begin{array}{c}\text { Gross } \\
\text { Margin }\end{array}$ & $\begin{array}{c}\text { Net } \\
\text { Margin }\end{array}$ \\
\hline 1. & Yamaker market & Chicken meat (carcass) & IDR/kg & 24,000 & 28,000 & 6,000 & 4,000 \\
& (Nunukan) & Chicken meat (wings) & IDR/kg & 28,000 & 33,500 & 5,500 & 0 \\
\multirow{2}{*}{ 2. } & Meat shop (Sebatik) & Culled layer (bird) & IDR/kg & 22,500 & 30,000 & 5,000 & 0 \\
& & Chicken meat (breast) & MYR/kg & 7.4 & 8.4 & 1.0 & 0 \\
& Chicken meat (thigh) & MYR/kg & 7.2 & 8.2 & 1.0 & 0 \\
& Chicken meat (wings) & MYR/kg & $8.5-9.5$ & $9.5-10.5$ & 1.0 & 0 \\
& Chicken meat (levers) & MYR/kg & 5.3 & 6.3 & 1.0 & 0 \\
& & MYg (Grade-C) & MYR/box $^{* 1}$ & 44.5 & 45.5 & 1.0 & 0 \\
& Egg (Grade-D) & MYR/box $^{* 1}$ & 43.5 & 44.5 & 1.0 & 0 \\
\hline
\end{tabular}

Note: ${ }^{* 1} 150$ eggs per box

Source: CBS-EK, 2010

\section{CONCLUSION AND POLICY IMPLICATIONS}

\section{Conclusion}

There are some conclusions based on the results of the study in the areas of Indonesian border. First, the extent of both active and passive surveillance was still law due to large coverage area, limited number of
PDSR human resources, and lack of report cases from poultry farmers. Second, the SOP conducted by quarantine institution was not fully implemented especially for controlling the HPAI. Third, the zoonotic case was mainly determined by clinical sign observation. Fourth, the level of coordination among cross-border institutions was still relatively worst so that the illegal 
trade was still occurred in the checkpoints and other entry points along the cross-border line. Fifth, live bird markets were mixed locate in the traditional market under inappropriate management. Sixth, due to different trade system implementation (per live bird vs. per $\mathrm{kg}$ ) in buying and selling the chickens in shed and market, traders tend to be actively visiting and catching the poultry in the sheds, and therefore the movement of poultry and poultry products was still risky. Seventh, there were some handicaps in line with local socio culture such as multi events festivity (gawai) with high consume of chickens and cock fighting activity in some spotted areas.

The summary of assessment results of risk indicators of cross-border study sites in West Kalimantan differs from that in East Kalimantan due to the different characteristics and the presence status of HPAI in each province. Risk indicators of the cross-border study sites in West Kalimantan Province were lower than those risk indicators in East Kalimantan Province because the province of West Kalimantan had ever declared as free of HPAI previously.

\section{Policy Implications}

Based on the aforementioned conclusions, some policy implications were made. First, it is suggested that active surveillance system together with zoonotic campaign should be implemented in order to obtain the immediate data and to attract poultry farmers to provide reporting on the case of HPAI in the respected areas. Second, clinical sign observation should be followed by PCR rapid test and laboratory analysis. Third, trade transaction should be gradually arranged in single system (per $\mathrm{kg}$ ) and poultry should be slaughtered in integrated hygienic slaughterhouses controlled by animal health authority. Fourth, live bird markets should be facilitated by integrated slaughterhouses initiated by community and local government units. Fifth, the multi event of cultural festivities should be managed in coordination of government and community such a way that implemented in Malaysia (all at once).
This study requires supporting primary and secondary data as well as direct field observation. At least there were two main constraints of the study. First, the results of the study were not optimal due to limited time availability for fieldwork activities. Second, the study was just conducted in Indonesian border side (without Malaysia), so that data were incomplete in line with the perspective of cross-border areas between Indonesia and Malaysia.

It is challenged to encourage the development of cross-border areas based on the results of the study through economic and infrastructure improvements. The comprehensive study should be conducted in collaboration with Malaysia to which it can be planned as lessons learned for other areas of Indonesia in the border with Malay Peninsula (Malaysia), Singapore, Philippines, Timor Leste, and Papua New Guinea.

\section{ACKNOWLEDGEMENT}

The authors wish to thank the Food and Agriculture Organization-Emergency Center for Trans-boundary Animal Disease-Regional Asia and the Pacific (FAO-ECTAD-RAP) especially Angel Ortiz-Pelaez PhD (veterinary epidemiologist) for the implementation of this study.

\section{REFERENCES}

CBS-EK. 2010. Kalimantan Timur Dalam Angka (East Kalimantan in Figures). Central Bureau of Statistics of East Kalimantan Province. Samarinda.

CBS-WK. 2010. Kalimantan Barat Dalam Angka (West Kalimantan in Figures). Central Bureau of Statistics of West Kalimantan Province. Pontianak.

DGLS-MoA. 2006. Pedoman Pemotongan Ayam dan Penanganan Daging Ayam pada Rumah Potong Ayam Skala Kecil (Guidelines on Chicken Slaughtering and Chicken Meat Handling in Small-scale Chicken Slaughterhouses). Directorate General of Livestock Services, Ministry of Agriculture of Indonesia. Jakarta. 
FAO-ECTAD-RAP. 2010. Indicator for Assessing the Risk of Cross-border Areas. Food and Agriculture Organization-Emergency Center for Transboundary Animal DiseasesRegional Office for Asia and the Pacific. Bangkok.

GoI. 1967. Border Trade Agreement (26 May 1967). Government of the Republic of Indonesia Jakarta.

GoI. 1984. Socioeconomic Malindo (MalaysiaIndonesia) task force (12 May 1984). Government of the Republic of Indonesia Jakarta.

GoI. 2008. Undang Undang (Law) No. 43/2008 tentang Wilayah dan Batas Negara (issued on Country Area Including Border Areas). Government of the Republic of Indonesia. Jakarta.

GoI. 2009. Undang Undang (Law) No. 18/2009 tentang Peternakan dan Kesehatan Hewan (issued on Livestock and Aanimal Health). Government of the Republic of Indonesia. Jakarta.

GoI. 2010. Peraturan Presiden (Presidential Regulation) No. 12/2010 tentang Badan Nasional Pengelola Perbatasan (National Agency for Border Management). Government of the Republic of Indonesia. Jakarta.

Hadi, S. 2010. Mengapa Kalbar Bebas AI? (Why West Kalimantan Free from HPAI?). Majalah Agroborneo (Agroborneo Magazine), Suara Pertanian Kalimantan (Kalimantan Agriculture Voice), No. 1 (1), 2010. Asosiasi Agribisnis Peternakan Provinsi Kalimantan Barat (Livestock Agribusiness Association of West Kalimantan Province). Pontianak.

Ilham, N. and M. Iqbal. 2011. Factors Determining Farmers' Decision on HPAI Vaccination at the Small-scale Coomercial Poultry Farms in Western
Java Area. Media Peternakan, Vol. 34, No. 3, December 2011: 219-228. Institut Pertanian Bogor. Bogor.

LDCC-EK, 2010. Jumlah Kasus Flu Burung dan Kematian Unggas di Provinsi Kalimantan Timur (Number of HPAI Case and Poultry Death in East Kalimantan Province). Local Disease Control Center of West Kalimantan Province, Samarinda.

LDCC-WK, 2010. Jumlah Kasus Flu Burung dan Kematian Unggas di Provinsi Kalimantan Barat (Number of HPAI Case and Poultry Death in West Kalimantan Province). Local Disease Control Center of West Kalimantan Province, Pontianak.

MoA. 2009. Peraturan Menteri Pertanian (Regulation of the Indonesian Ministry of Agriculture) No. 20/Permentan/OT.140/4/2009 tentang Impor Pengawasan Distribusi Karkas, Daging, dan/atau Jeroan (issued on Import and Distribution Control Carcasses, Meat, and/or Innards). Ministry of Agriculture of Indonesia. Jakarta.

Rushton, J., W. Kalpravidh, E. Marshall, N. de Haan, P. Ankers, N.M. Taylor, V. Martin, G. Fusheng, D. Castellan, S. Morzaria, J. Domenech. 2009. Cross border trade and HPAI risk reduction in the Greater Mekong Sub-Region. International Symposia on Veterinary Epidemiology and Economics proceedings, ISVEE 12: Proceedings of the 12th Symposium of the International Society for Veterinary Epidemiology and Economics, Durban, South Africa.

USAID. 2007. Audit of USAID's Avian Influenza Efforts. Report No. 9-000-07007-P. United States Agency for International Development. Washington DC. 